\title{
Green Banking: A Service Product Innovation In Brand Image Enhancement Through The Marketing Mix
}

\author{
Terra Saptina Maulani \\ STIE Ekuitas \\ terra.saptina@ekuitas.ac.id
}

\begin{abstract}
Energy crisis and environmental phenomena such as climate change, natural disasters and global warming affect many countries. These are caused by the excessive exploitation of natural resources resulting in environmental damage. Economic growth and industrial activities are blamed for contributing to the problems. As a financial institution, Bank has an important role in addressing some of these phenomena with Green Banking by giving priority to the sustainability development in its business practices. The application of Green Banking can ultimately generate the output of operating cost efficiency, competitive advantage, corporate identity and a strong brand image as well as the achievement of a balanced business target.

This paper is aimed at illustrating the application of Green Banking as one of the product innovations in banking services such as the reduced wastage of papers and energy through net banking approach, online bill system, estatements registration and any service activity directly perceived by costumers. Green Banking application is expected to improve the brand image in the mind of customers by the proper implementation of the marketing mix. It is because marketing mix is a tool or strategy undertaken by the organization in creating, communicating, and delivering value to customers.

This research is a qualitative and descriptive research using literature study as the method of analysis. The results of this paper are intended especially for banking organizations to enhance their brand image as a positioning strategy by concerning about the environment.
\end{abstract}

\section{Keywords: Green Banking, Marketing Mix, Brand Image}

\section{Introductions}

Energy crisis and environmental phenomena such as climate change, natural disasters and global warming affecting many countries caused by the exploitation of natural resources resulting in excessive environmental damage. Almost all countries seek to reduce the impact of climate change. Environmental issues are one of them triggered by the economic and industrial development is so rapid, that is of particular concern various parties. Financial institutions also affect the economic growth and development both in terms of quality and quantity, and therefore, the current banking sector has an important role in determining sustainable environment.

The green banking is a long-term business strategy that besides aiming profit also scored benefit to the empowerment and sustainable environmental conservation. Based on the World Bank, Green Banking has four elements of the nature of life, well-being, economy and society. The green banking combines four elements in the principle that businesses care about the ecosystem and the quality of human life, which in turn can generate output such as operating cost efficiencies, competitive forte, corporate identity and a strong brand image as well as the achievement of a balanced business that is not only pursuing profit but also care about the people and the planet. The good brand image is not formed by itself but requires strategy in developing it, through the tool that marketing mix strategy to creating, delivering and communicating customer value that is not only profitable but concerned about the environmental factors. The marketing mix strategy that includes seven elements of the product, price, place, promotion, people, process and physical evidence.

\section{Literature Review}

\section{Green Banking is The Innovation}

The external environment changes, such as climate change, environmental degradation, triggering a bank in the way of implementing green business practices, which does not only think of the profit factor, but the people and planet. It encourages innovation in organizations, especially banks. The innovation plays an important role for excellence organization. According Fonata (2011) innovation is the economic success because of the introduction of a new way or a new combination of old ways of transforming inputs into outputs (technology) that produce large or drastic changes in the ratio between use value perceived by the consumer on the benefits or products and the price set by the manufacturer. In today's banking world, the concept of green banking has been implemented in order to create sustainable development. Green Banking, an effort by the banks to make the industries grow green and in the process restores the natural environment (Bhardwaj and Maholtra, 2013). Green banking refers to the banking business conducted in such areas and in such a manner that helps the overall reduction of external carbon emission and internal carbon footprint (Green, 1989). Biswas (2011) Green banking means combining operational improvements, technology and changing client habits in banking business. Green banking refers to how enviromentally the bank is, and how commited to green and etnical policies they are (Sharma et 
al, 2013). The orientation of the concept of green banking is not just focused on the moment, but more focused sustainable development for the future.

The adoption of green banking strategies will help the bank to deal with these risks involved in their business operation, Green banking strategies involves two components such as Managing environment risk and Identifying opportunities for innovative environmentally oriented financial products (IFC, 2007; Biswas 2011). To manage environmental risk, the banks have to design proper environmental management systems to evaluate the risks involved in the investment projects. The risks can be internalized by introducing differential interest rates and other techniques. Moreover, bank can withdraw itself from financing high-risk projects. The second component of green banking entails creating financial products and services that support commercial development with environmental benefits. These includes investment in renewable energy projects, biodiversity conservation, energy efficiency, investment in cleaner production process and technologies, bonds and mutual funds meant for environmental investments etc.

Green banking is a very different approach than some of the previous decade in the banking sector in doing business. Innovation is needed is not only intended to maximize the financial side, but by taking into account social and environmental factors as well as focusing on the needs and desires of customers, which in turn will create sustainability. Innovation which has created a new value needs to delivered and communicated to the customer as the primary users, through a strategy so as to create a positive image in the minds of consumers to the organization, in this case the bank. Green Banking helps to create effective and reaching market-based solutions to address a range of environmental problems, including climate change, deforestation, air quality issues and biodiversity loss, while at the same time identifying and securing opportunities that benefit customers and it has major benefits of green banking are Avoids paper work, creating awareness to business people about environment sanctioning loans at comparatively lesser rates, environmental standards for lending (Bahl,2012).

\section{Marketing Mix}

Currently, the company is volatile macro environment; banking companies are required to keep maximizing profit but should pay attention to environmental factors, and on the other hand, must be able to anticipate the needs and desires of customers who increasingly complex. The company should be able to implement marketing strategies that can improve the customer, know more about the wishes and needs of customers, addressing the threat of competition and strengthen the competitive advantage so that customers will feel more satisfied in using the products or services offered by the company (Cravens, 2009). Green banking is an innovation that has a value that is currently being implemented by banks to customers, so that the effective value then the marketing mix is a tool to achieve the goals within the organization to be more effective than competitors in creating, delivering and communicating value to the selected target market (Kotler dan Keller, 2012). Banking is an organization of companies engaged in the field of services, for creating, delivering and communicating the value needs product, price, place, promotion, people, process and physical evidence.

Product is everything that is offered to the market to satisfy a wants and needs including physical goods, services, experiences, events, people, places, properties, organizations, information and others (Kotler and Keller, 2012). Bank is an institution whose main activity is to collect funds from the public and distribute the funds back to the community and provide other banking services, while the bank's main product is the product of funding (savings, time deposits, and demand deposits), the product lending (loans or credit facilities) or other bank services (Kasmir, 2000: 169). Firms can green their product/ services by introducing new environmentally friendly product/ product lines into establish catagories by developing new product in new catagories by modifying existing procuct atributes and made them greener or by developing less harmfull production process. The green product mix includes, minimize the negative environmental effects of waste and pollution of the production process, not limited usage of raw materials, ensure the usage environmentally friendly products by the help of service department, less raw materials (Maria 1999; Pinter et al, 2006 ). In the traditional approach, the customer comes to the bank to perform a variety of transactions, but this time an innovation has occurred, through a green approach to banking in addition to facilitate the customer, is also very beneficial for the organization itself. Such as green checking, green loans, e-statement registration, net banking appoach for reduce wastages of papers and energy, online bill payment, cash deposite system, E- investment service, thre're the green banking initiative by bank and its awerebess among their customers (Sharma et al, 2013). Green Banking product overage includes green mortgages, green loans, green credit cards, green savings accounts, green checking accounts, green money market accounts, mobile banking, online banking, remote deposit (Bahl, 2012).

Price, one of the elements of the marketing mix that produces revenue, as well as the easiest element in the marketing mix programs to suit the product features, channel and communication (Kotler and Keller, 2012). Customers to get a service would require a sacrifice that is the price that has been determined based on company policy. Place, relating to disturbing a service that is used by the company. Greening of place can involve; consumer market of can focus on the physical distribution process (Orosdy, 2005; Pinter et al, 2006). Promotion, aims to remind, persuade, providing information to influence consumer behavior (Kotler and Keller, 2012). Green promotion policy can stimulate demand for green service customers can enhance corporate image, in which the company can use various policies such as the explanation of ecological problems, information about green services, environmentally conscious sales promotion, PR activity environmentally friendly, and give information about the environmental effects of corporate performance to the 
market (Pinter et al, 2006)

People, the human resources within the company, without the company people cannot run, because people is one important element in the delivery of services. One feature of the service is the inseparability where the service cannot separate from their providers (Kotler and Keller, 2012). Even with all system simplicity to customers, banks still need people in its operation as service providers for ongoing services and consumption process, which can certainly affect the perception of the buyer. Process, a mechanism, flow of activities, number of steps in an effort mempeoleh product customers (Zeithaml et al, 2000). While physical evidence an environment where services performed where service providers and consumers interact, and there is a tangible component (exterior and interior environment) which facilitates the performance of services such as building good condition. Physical evidence may include facility design, equipment, sign age, employee dress, other tangible (Zeithaml et al, 2000).

\section{Brand Image}

Brand Image is an impression that the consumer against a bank as a reflection or evaluation of the relevant bank. Brand Image can be formed by two factors: communication and customer experience for a customer of the bank. Communication between an organization and the public can be influenced by consumers' perception of the organization, as well as customer experience, both directly and indirectly related to the provision of products or services. If customers get the quality of banking services that satisfy the customers tend to have a positive perception of the bank. Jefkins in Soemirat and Adrianto (2007: 114) states that the image of a person or an individual impression of something that emerged as a result of knowledge is and experiences. Nguyen and LeBanc (2001) corporate image is related to the different physical and behavioral attributes of the company, like business name, architecture, variety of goods or services, traditions, ideology and to the feeling of quality communicated by each person interacting with the clients of the company. Kotler and Armstrong (2012: 559) argues that the image is a set of beliefs, ideas, impressions held by a person of an object.

Competition increasingly competitive business, create a banking company in this case trying to improve advantages. Imagery is a very valuable asset because it has benefits for enterprise organizations, while some of the benefits of the image according to Sujoto (2004: 3 ) is able to create the ability to compete with steady in the medium and long term, become a shield for the company for the company is in a crisis, be consumer appeal of the company, improve the effectiveness of marketing strategies, saving operational costs.

Image formation is due to the perception initially thought or perceived by the customer. Solomon in Soemirat (2007: 114) states that the attitude rooted in cognitive organization of information and knowledge. Attitude is a tendency to act, to percept, to think and to feel in the face of the object, idea, situation or value. A good image is not formed itself but require special strategies to build it.

\section{Purpose and Research Methodology}

The purpose of this paper is to investigate the role of green banking in enhancing the image through marketing mix. This research is a qualitative and descriptive research using literature study as the method of analysis.

\section{Discussions}

Currently the macro environment is volatile, especially the natural environment that experienced significant climate change. It occur in almost all countries in the world. Industrial and economic development of the accused to be one that contributes to it, so that today in almost every country in the world are trying to minimize it. With the efforts that are "green" in the hope of minimizing the environmental impact but still can maximize profit.

Currently the phenomenon has prompted changes in the business world. Changes in the external environment to encourage internal changes run the organization in its business processes. One of them in the realm of banking, banking Green concept is a long-term business strategy that besides aiming profit also scored benefits to the empowerment and sustainable environmental conservation, not only for the current impact, but also the future.

According to the World Bank, the application of green banking by setting elements such as nature, wellbeing, economy and society, which in turn will produce output that one of them is an identity and a strong brand image. The act of designing the company's brand in order to get a special place in mind the target market, the goal is to get the brand in the minds of consumers to maximize the potential benefits for the company called positioning (Kotler dan Keller, 2012). Brand Image is an impression that a consumer against a bank as a reflection or evaluation of the relevant bank. Image awakened in the minds of consumers are not created simply but require a strategy that is by developing a marketing mix for each target market destination. The marketing mix is a means to an organization with the goal to be more effective than competitors with creating, delivering and communicating superior customer value on the selected target market (Kotler dan Keller, 2012: 27).

Environmental changes create a new concept of "green banking" which encourages banks to make a change in its business activities so as to create new value in the form of a new innovation in the form of new products and services that have a better value for consumers and organizations. In this case green banking encourage the creation of products that sound environmental services such conduct entails creating green banking financial products and services that support commercial development with environmental benefits.

From the customer side, the traditional approach is slowly becoming obsolete in which customers come to the bank just to save money, withdraw cash, check balances, trasfers which is where all transactions are done in place, meaning no more sacrifices in terms of time and energy spent by the customer to obtain a service. Currently, all these things can be done easily without having to go to the bank to make a transaction. The green checking, green 
loans, e-registration statement, net banking approach, online bill payment, cash deposit system, E- investment service. On the one hand that has benefits for consumers, the application of green banking also has benefits for the organization that is the cost efficiency because it seeks to control and reduce energy usage, paperless and efforts of other efforts. In addition, the "green" banking products are the provision of credit to environmentally sound projects.

Everything offered by organization to customers, of course, require a reciprocal of the customer throughout the organization on the form of price. This price is the amount of money issued by the customer on product performance service that has been consumed. With the ease of consumers transaction through a number of innovative banking products offered such as online banking, ATM transactions, and of course there are other costs incurred in each period. Shape price "green" can be periodically costs has contributed to the activities of environmentally sound but the amount depends on the policy of each bank, for example, of the contribution of these costs can be donated to environmental care organizations organization- like green peace, WWF and others.

The place in this case focuses on the distribution of services directly to customers, the ease of reaching customers enjoyed the product or service that has been provided by the bank, such as the ease of reaching the location and transportation, would be better if these facilities are spread widely and it is strategically located, such as ATM location, or cash deposit systems are easily found, and many scattered in a particular region. Not only that, the customer must also be able to enjoy the product through the net - services system that is easy to use. It is useful to facilitate customers achieve and enjoy the product.

The promotion function is to remind, encourage and influence consumer behavior, the "green" promotion system with an attempt to explain and inform the public that the resulting product service "green", environmentally friendly use of media in doing advertising such as the use of recycled paper for brochures, follow the activities or sponsoring the event with environmental, and inform various corporate performance "green" to the market. it can affect the market for the organization cognitively.

All of these activities require human activities to run, despite the presence of technology can enable customers to conduct banking transaction, for example, if customers feel difficulty in consuming the product, we need a guide for the people as the front line organizations that deal directly with customers who can be found directly, through the call center, online service center or by email. So behind every "green" innovation products needs people .

The process relates to the procedures, mechanisms and flow of movement activity of banking services, how the customer can get the products offered of course required a certain mechanism to get it. The process is done would be better if simpler, not complex. The process is one of the important things in service because customers often determine the decision of the election is simply the process for, will come and after the use of services.

The physical environment is the space by which customers surrounded when consume the service. The physical environment is made up from its ambient conditions, spatial layout and functionality, and signs, symbols and artefacts (Zeithaml et al, 2000). Physical evidence is the physical condition (tangible) that supports the services process includes exterior and interior environment that facilitates the performance of services such as building good condition and environmentally sound. The physical condition of the "green", plants crops can be found in nearby services.

Implementation of the "green" marketing mix in banking is expected to generate output for organizations that increase brand image. Imagery is defined as the perception of the brand that reflected the existing brand associations in consumer memory, and consists of all hope and knowledge that relate to specific products or service's brand association is a node other information related to the brand node in memory and the brand means to consumers (Keller, 1993).

Banks' brand image does not suddenly increase if not applied an effort, namely the applications of the marketing mix, with "green" innovative banking products, price, place, promotion, people, process, and physical evidence optimally. Rajh \& Dosen (2009) various elements of the marketing mix can affect brand equity services. Service delivery activities, atmosphere, marketing communications will provide a non-financial benefit of increased brand image (Akroush and Al-Dmour,2006).

\section{Conclution}

Changes in the macro environment, especially nature that is increasingly unstable and marked by numerous disasters that occur almost worldwide. Currently, many countries are trying to reduce the climate impact. The external changes prompted many organizations to make changes in their business activities, including banking. With the adoption of a new concept that is green banking, will encourage a new innovation. Application of the green banking strategy will produce one output in the form of brand image. Brand image is an important aspect in the organization. However, the image cannot just show up in the minds of consumers. It is necessary efforts to reach, by applying marketing mix optimally.

\section{References}

Akroush, M., \& Al-Dmour, H. (2006). The Relationship between Brand-Building Factors and Branding Benefits in Commercial Banks Operating in Jordan: An Empirical Investigation of managers' perspectives. Jordan Journal of Business Administration p.464-486

Al-Dmour, H,. Al-Zu'bil, M F and Kakeesh, D. (2013). The Effect of Services Marketing Mix Elements on Customer-Based Brand Equity: An Empirical Study on Mobile Telecom Service Recipients in Jordan. International Journal of Business and Management Vol. 8. Published by Canadian Center of Science and Education

Bahl, S. (2012). Green Banking - The New Strategic 
Imperative. Asian Journal of Research in Business Economic and Management Vol 2.

Bhardwaj, B.R,. Maholtra, A. (2013). Green Banking Strategies: Sustainability throughCorporate Entrepreneurship. Greener Journal of Business and Management Studies Vol. 3 pp. 180-193

Fonata, A.(2011). Innovative We Can. Cipta Inovasi Sejahtera, Jakarta

Green, C. F. (1989). Business Ethics in Banking. Journal of Business Ethics 8.8:631-634

Nguyen,N and LeBanc, G. (2001). Image and reputation of higher education institutions in studens's retention decesion. Int joural of education management. Vol 15 Issue: 6 , pp 303-311

Kashmir. (2000). Manajemen Perbankan. Jakarta: PT Grafindi Persada

Keller, K L . (1993). Conceptualizing, Measuring, and Managing Customer-Based Brand Equity.Journal of Marketing Vol. 57, No. 1 (Jan., 1993), pp. 1-22. Availablehttp://www.jstor.org/stable/1252054

Kotler, P and Keller, K L. (2012). Marketing Management. Pearson Prentice Hall

and Armstrong. (2012). Principal of Marketing 14th Edition. Pearson Prentice Hall

Pinter, E,. Deutsh, N and Ottmar, Z. (2006). New Direction Line of Suistainable Development and Marketing in Green Banking. Available www.ssrn.com

Sharma, N,. Sarika, K and Gopal, R. (2013). A Study On Customers's Awareness on Green Banking Initiatives in Selected Public and Private Sector Banks with Special References to Mumbai. IOSR Journal of Economic and Finance p.28-35

Sujito, S. (2004). Membangun Citra Perusahaan. Jakarta: Damar Mulia Pustaka

Soemirat, S and Andrianto, E. (2007). Dasar Dasar Public Relation. Bandung: PT Remaja Rosdakarya

Rajh, E and Došen, D. (2009). The Effects Of Marketing Mix Elements On Service Brand Equity. Economic Research p.69-83

Yoo, B., Donthu, N., \& Lee, S. (2000). An examination of selected marketing mix elements and brand equity. Journal of the Academy Of Marketing Science p.195211. http://dx.doi.org/10.1177/0092070300282002

Zeithmal, Valerie A,. and Bitner, Mary Jo. 2000. Service Marketing: Integrated Customer Focus Across the Firm. Singapore: McGrow Hill 